\title{
General Tendencies of the Behaviour of Vegetables Developed in a Soil Contaminated with Heavy Metals
}

\begin{abstract}
AUGUSTINA PRUTEANU ${ }^{1}$, VALENTIN VLADUT ${ }^{1 *}$, PETRU CARDEI ${ }^{1}$, DESPINA BORDEAN ${ }^{1,2}$
${ }^{1}$ National Institute of Research-Development for Machines and Installations Designed to Agriculture and Food Industry, INMA, 6 Ion Ionescu de la Brad Str., 013813, Bucharest, Romania

${ }^{2}$ Banat's University of Agricultural Sciences and Veterinary Medicine "King Mihai I of Romania" from Timisoara, 119 Calea Aradului, 300645, Timisoara, Romania

The paper presents experimental results obtained in the study of heavy metals transfer from soil to vegetables. The experiments for which the raw and statistically processed data are presented in this paper are preliminary experiments within an extensive research program of plant behaviour in soils contaminated with heavy metals. These experiments underlie the development of primary statistical mathematical models that are also presented in the paper. These experiments will also form the basis for far more consistent experiments that follow plants throughout the life cycle. The statistical mathematical models presented in this paper facilitate extracting important conclusions about how plants accumulate heavy metals as well as about the accumulation rate behaviour during experiments. Both experiments and mathematical models will form the basis of complex experiments and dynamic mathematical models in the next stage of research.
\end{abstract}

Keywords: vegetables, heavy metals, transfer, statistical models

The issue of heavy metal accumulation in plants is currently debated in an extremely extensive literature. Attempts to achieve original results in this domain are related in particular to changing the viewpoint on experimental activity, to see plants as entities that have a much longer life than what most people know. Plants live far beyond the vegetation cycle, and the general phenomena in the plant during lifetime after the end of the vegetation cycle are extremely interesting both for the study of life itself and for the particular problem of heavy metal accumulation [1].

Numerous experiments are described in the literature [2-4]. This literature dedicated to modeling and accumulation of heavy metals defines a satisfactory framework for obtaining immediate results $[1,5]$.

The analyzed vegetables proved to have different capacity of bioaccumulation, depending on plant species, type of metal, type of soil, etc. $[6,7,8]$. Heavy metals can be readily taken up by vegetable roots, and can be accumulated at high levels in the edible parts of vegetables, even heavy metal in soil at low levels. However, very few studies have investigated multiple heavy metals $(\mathrm{Pb}, \mathrm{Cd}, \mathrm{Cu}, \mathrm{Zn}$, and $\mathrm{As})$ in soils. Therefore, in the study [9], field experiments were carried out on $\mathrm{Pb}, \mathrm{Cd}, \mathrm{Cu}, \mathrm{Zn}$, and As contaminated farmland near Shizhuyuan Mine Zone in Chenzhou City, southern Hunan Province, China, where 22 vegetable species (six vegetable types) were used in the trials. The main purposes of this study were to investigate the concentrations and accumulation of $\mathrm{Pb}, \mathrm{Cd}, \mathrm{Cu}, \mathrm{Zn}$, and $\mathrm{As}$ in the edible parts of different vegetable species, and to assess the health risks of vegetable consumption on residents (adults and children).

In Romania, the authors of the paper [10] present the research results obtained in 2011 in SIECOLEG project regarding the assessment of some heavy metals (mainly lead, cadmium, cooper, and manganese) of soils and vegetables from some growing systems. The mean heavy metals levels $(\mathrm{Pb}, \mathrm{Cd}, \mathrm{Cu}, \mathrm{Mn}, \mathrm{Zn})$ in soil and vegetable samples analyzed in 2011 were in the admissible limits in concordance with European Reglementations.

This paper presents the results obtained for several experiments extensively carried out following the observations to be used in a stage of plant species to be taken up to 2-3 cycles of vegetation for the study of heavy metals in descendants. The basic parameters for the characterization of heavy metal accumulation in plants have behavioural characterization in the results outlined in this article.

\section{Experimental part}

Materials and methods

The studied vegetables (carrots, radishes, parsley leaves and root, spinach, cucumbers, tomatoes), fig.1, were planted in soil contaminated with the following four heavy metal concentrations: $1.5 \%, 3.0 \%, 4.5 \%, 6.0 \%$ and the heavy metals used were: copper, lead, zinc. The vegetables under study were planted in a controlled medium, using pots to which contaminated soil was added with four concentrations of $\mathrm{Cu}, \mathrm{Pb}, \mathrm{Zn}$ mixtures. The solutions with concentrations of 1.5, 3.0, 4.5 and $6.0 \%$ were prepared individually using copper sulphate, lead acetate and zinc sulphate as reagent, the solvent used in the preparation of the solutions being distilled water. The pots in which the

*email:valentin_vladut@yahoo.com 
vegetable seedlings were planted were filled with fertile soil that was mixed and homogenized in turn with each of the four solutions of different concentrations. For each pot the added soil was $250 \mathrm{ml}$ of $\mathrm{Cu}, \mathrm{Pb}, \mathrm{Zn}$ mixture solution per 1 $\mathrm{kg}$ of soil. In experiments, heavy metal loading was performed by initially loading the soil with each of the four mixture concentrations of $\mathrm{Cu}, \mathrm{Pb}, \mathrm{Zn}$, without supplementing until harvest. In contrast to the soil contaminated with the four solutions of different concentrations, in parallel as reference samples, seedlings were planted in pots with uncontaminated fertile soil. The physicochemical properties of the uncontaminated soil (considered the control sample) were: $\mathrm{pH}$ 5.0-7.0; total nitrogen $1.9 \%$; total phosphorus $0.5 \%$; total potassium $0.9 \%$; electrical conductivity 1.2; particle elements over $20 \mathrm{~mm}$ maximum $5 \%$, humidity $14.7 \%$. Determination of $\mathrm{Cu}, \mathrm{Pb}, \mathrm{Zn}$ from the contaminated soil and from the leaves and roots of the studied vegetables was done by spectrophotometric method (flame atomic absorption) [11].

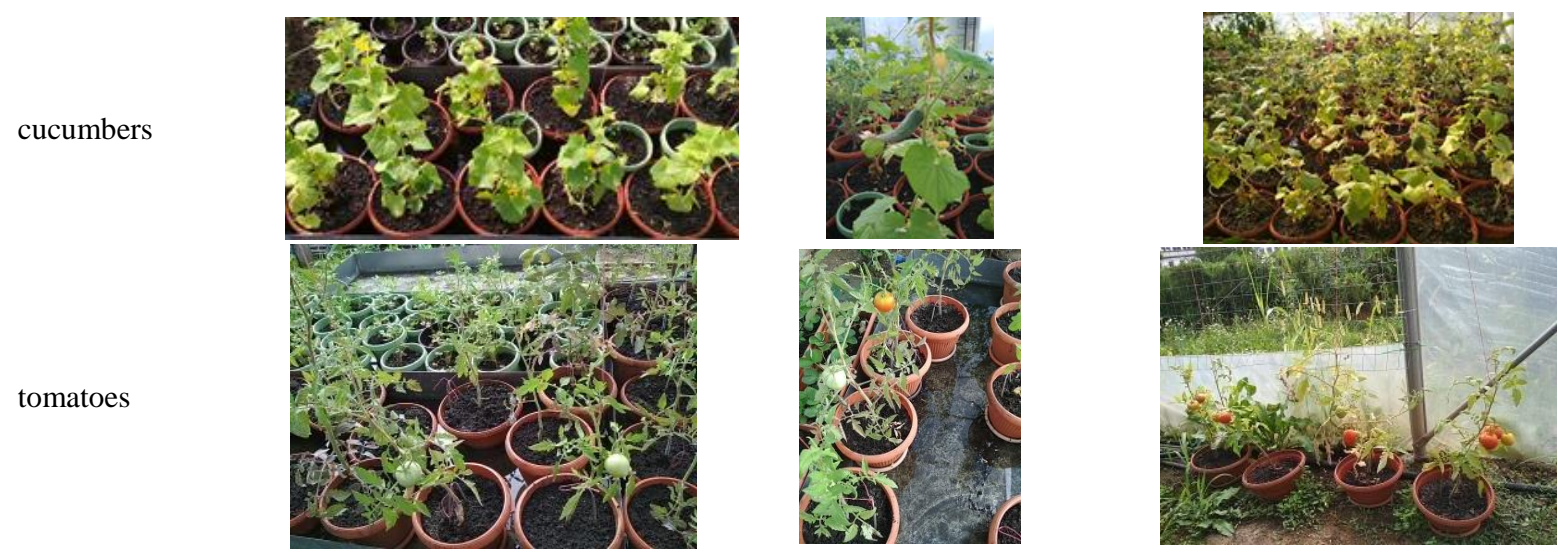

Fig. 1 The state of development of some vegetables

Mathematical modeling in the field of biological phenomena presents two types of fundamental models. The first type of models is obtained statistically and starts from raw experimental data. The second type of mathematical models are of a dynamic type and are obtained from some refined methods of statistical modeling and application of general principles to basic entities that define the biological material. In this paper, only statistical models will be presented. The exposed statistical models are simple and contain only the interpolation by polynomial functions of the raw experimental data. The interpretation of these models will also be provided. Generally, these simple models underlie the creation of dynamic elementary models.

\section{Results and discussions}

Using the experimental results and their graphical representations, interpolation curves were obtained for the variation of the heavy metal content in the plant according to the heavy metal content in the initially contaminated soil, as well as for the variation of the heavy metal transfer coefficient to the plant according to the heavy metal content in the initially contaminated soil. Curves describing the heavy metal content variation in the plant, according to the heavy metal content in the initially contaminated soil, show two distinct types of variation. The first type of variation curves are monotonically increasing curves where most of the vegetables considered in experiments fall, as can be seen in table 3.1. The second type of variation curves of the heavy metal content in the plant, according to the heavy metal content in the initially contaminated soil, shows a maximum at a given concentration of heavy metal in the soil. This type of behaviour was found in approximately one third of experiments (Table 1).

Table 1

VARIATION OF DEPENDENCY CURVES OF HEAVY METAL CONCENTRATION IN THE PLANT AND IN THE SOIL PER PLANT SPECIES

\begin{tabular}{|l|c|l|}
\hline Plant & $\begin{array}{c}\text { Increasing } \\
\text { percentage }\end{array}$ & Oscillating curves percentage \\
\hline Carrots & $\mathbf{6 6 . 6 7}(\mathrm{Pb}, \mathrm{Zn})$ & $\mathbf{3 3 . 3 3}(\mathrm{Cu})$ \\
\hline Radishes & $\mathbf{1 0 0}(\mathrm{Cu}, \mathrm{Pb}, \mathrm{Zn})$ & - \\
\hline Parsley roots & $\mathbf{6 6 . 6 7}(\mathrm{Pb}, \mathrm{Zn})$ & $\mathbf{3 3 . 3 3}(\mathrm{Cu})$ \\
\hline Parsley leaves & $\mathbf{6 6 . 6 7}(\mathrm{Pb}, \mathrm{Zn})$ & $\mathbf{3 3 . 3 3}(\mathrm{Cu})$ \\
\hline Spinach & $\mathbf{6 6 . 6 7}(\mathrm{Pb}, \mathrm{Zn})$ & $\mathbf{3 3 . 3 3}(\mathrm{Cu})$ \\
\hline Cucumbers & $\mathbf{6 6 . 6 7}(\mathrm{Cu}, \mathrm{Zn})$ & $\mathbf{3 3 . 3 3}(\mathrm{Pb})$ \\
\hline Tomatoes & - & $\mathbf{1 0 0}(\mathrm{Cu}, \mathrm{Pb}, \mathrm{Zn})$ \\
\hline
\end{tabular}

A graphical representation of a variation of the heavy metal content in the plant according to the heavy metal content in the initially contaminated soil, with the monotonically increasing character, is shown in figure 2 . A 
graphical representation of a variation of the heavy metal content in the plant according to the heavy metal content in the initially contaminated soil, with a maximum position, is shown in figure 3 .

The curves describing the variation of the heavy metal transfer coefficient to the plant, depending on the heavy metal content in the initially contaminated soil, tend to have a mostly decreasing trend after an approximately parabolic curve. There have also been some curves that are exceptions to this behaviour, with small deviations from the behaviour mentioned above, but these are few and yet random in nature and should be studied further, as shown in table 2 .

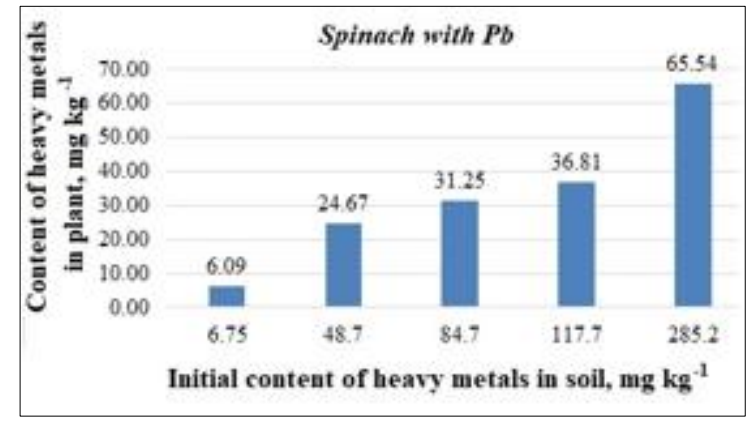

Fig. 2. Typical variation of heavy metal content in the plant, monotonous

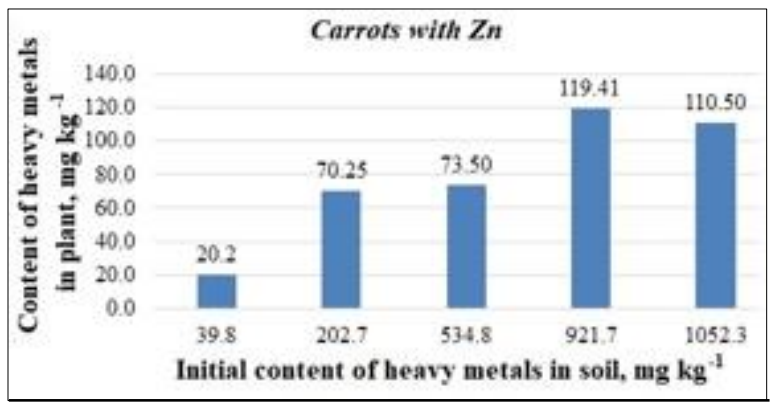

Fig. 3. Typical variation of heavy metal content in the plant. with maximum position

Table 2

VARIATION OF DEPENDENCY CURVES OF HEAVY METAL TRANSFER COEFFICIENT FROM SOIL TO PLANT

\begin{tabular}{|c|c|c|}
\hline Plant & $\begin{array}{c}\text { Decreasing curves } \\
\text { percentage }\end{array}$ & $\begin{array}{c}\text { Oscillating curves } \\
\text { percentage }\end{array}$ \\
\hline Carrots & $\mathbf{1 0 0}(\mathrm{Cu}, \mathrm{Pb}, \mathrm{Zn})$ & $\mathbf{0}$ \\
\hline Radishes & $\mathbf{6 6 . 6 7}(\mathrm{Cu}, \mathrm{Pb}, \mathrm{Zn})$ & $\mathbf{3 3 . 3 3}(\mathrm{Zn})$ \\
\hline Parsley roots & $\mathbf{6 6 . 6 7}(\mathrm{Cu}, \mathrm{Zn})$ & $\mathbf{3 3 . 3 3}(\mathrm{Pb})$ \\
\hline Parsley leaves & $\mathbf{3 3 . 3 3}(\mathrm{Cu})$ & $\mathbf{6 6 . 7}(\mathrm{Pb}, \mathrm{Zn})$ \\
\hline Spinach & $\mathbf{1 0 0}(\mathrm{Cu}, \mathrm{Pb}, \mathrm{Zn})$ & $\mathbf{0}$ \\
\hline Cucumbers & $\mathbf{1 0 0}(\mathrm{Cu}, \mathrm{Pb}, \mathrm{Zn})$ & $\mathbf{0}$ \\
\hline Tomatoes & $\mathbf{6 6 . 6 7}(\mathrm{Pb}, \mathrm{Zn})$ & $\mathbf{3 3 . 3 3}(\mathrm{Cu})$ \\
\hline
\end{tabular}

A variation curve of the heavy metal transfer coefficient from soil to plant, depending on the heavy metal content in the contaminated soil is shown in figure 4.

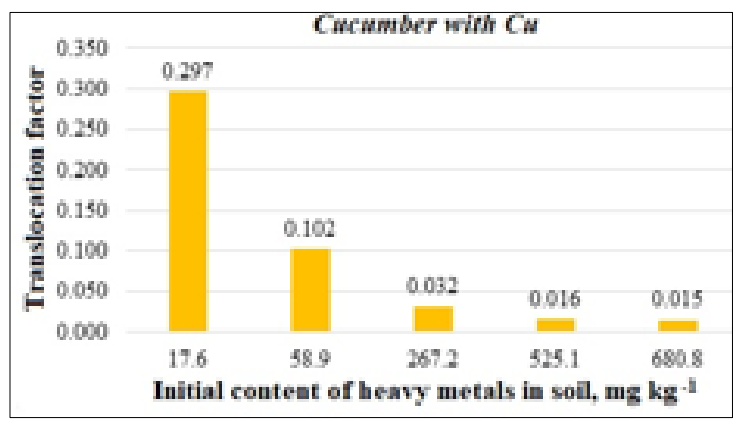

Fig. 4. Typical variation curve of the transfer coefficient

The transfer coefficient was calculated with relation $1[6,12]$ :

$$
C_{t}=\frac{C_{f p}}{C_{i s}}
$$


where: $C_{t}$ is the transfer coefficient; $C_{f p}$ is the final metal content in the plant $\left(\mathrm{mg} \mathrm{kg}^{-1}\right) ; C_{i s}$ is the initial heavy metal content in the initially contaminated soil $\left(\mathrm{mg} \mathrm{kg}^{-1}\right)$.

\section{Statistical mathematical models}

Using the experimental data distributions as shown in Figures 1,2 and 3 and the classical interpolation methods provided by mathematical statistics, interpolation curves of first, second, third or higher degree can be obtained.

The most common interpolation statistical curves, in the absence of theoretical information about the behaviour of the studied parameters (the heavy metal content in the plant, the transfer coefficient), are the polynomial curves. Having no other information about a predicted theoretical behaviour, on the studied parameters, we obviously chose the simple variant of polynomial interpolation. For the cases graphically represented in figures 2,3 and 4 , the mathematical models of the behaviour of the same parameters, represented graphically in figures 5, 6 and 7, are obtained.
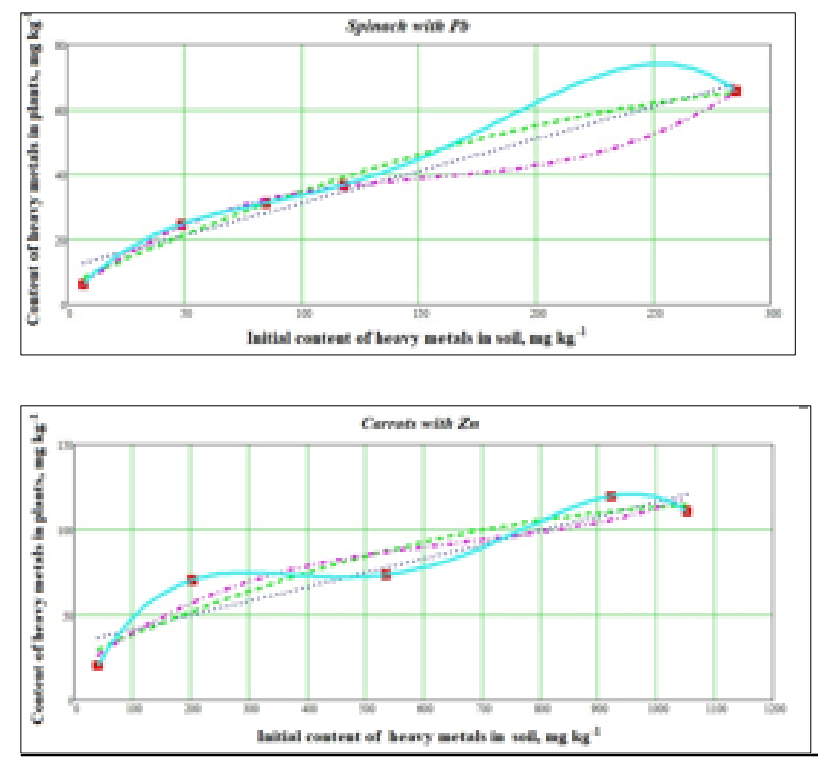

Fig. 5. Interpolation curves of heavy metal content in spinach leaves at harvest depending on $\mathrm{Pb}$ content in the soil

Fig. 6. Interpolation curves of heavy metal content in carrots at harvest depending on $\mathrm{Zn}$ content in the soil

The general form of the interpolation polynomial (degrees one - four) is given in equation 2 :

$$
C\left(C_{i s}\right)=c_{0}+c_{1} C_{i s}+c_{2} C_{i s}^{2}+c_{3} C_{i s}^{3}+c_{4} C_{i s}^{4}
$$

where: is the metal content in the plant or the transfer coefficient according to the data used in the interpolation. Coefficients $c_{0}$ to $c_{4}$ for $C$.interpolation are shown in Table 3.

For the transfer coefficient, the way the experimental data is placed shows a possible monotonous decreasing, possibly asymptotic, mathematically modelable according to relation 3 :

$$
C_{t}\left(C_{i s}\right)=\frac{c_{0}}{C_{i s}}+c_{1}
$$

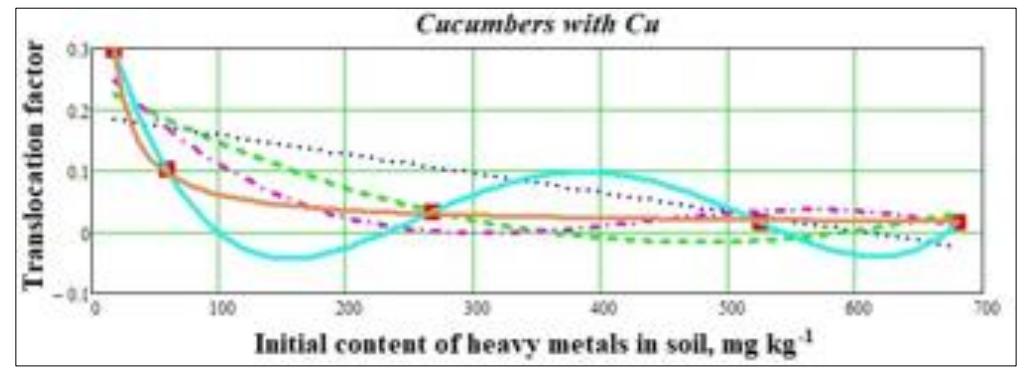

Fig. 7. Interpolation curves for transfer coefficient to cucumbers in $\mathrm{Cu}$ contaminated soil 
Table 3

INTERPOLATION EQUATIONS AFFERENT TO VEGETABLES

\begin{tabular}{|c|c|c|c|c|c|c|c|}
\hline \multirow{2}{*}{ Vegetable } & \multirow{2}{*}{ Metal } & \multicolumn{5}{|c|}{ Coefficients of interpolation polynomials } & \multirow[t]{2}{*}{ Error*,\% } \\
\hline & & $\mathbf{c}_{0}$ & $\mathbf{c}_{1}$ & $\mathbf{c}_{2}$ & $\mathbf{c}_{3}$ & $\mathbf{c}_{4}$ & \\
\hline \multirow{4}{*}{ Carrot } & \multirow{4}{*}{$\mathrm{Zn}$} & 33.157 & 0.083 & 0 & 0 & 0 & 37.801 \\
\hline & & 23.598 & 0.153 & $-6.353 \cdot 10^{-5}$ & 0 & 0 & 33.614 \\
\hline & & 16.381 & 0.261 & $-3.304 \cdot 10^{-4}$ & $1.655 \cdot 10^{-7}$ & 0 & 31.78 \\
\hline & & -6.277 & 0.759 & $2.493 \cdot 10^{-3}$ & $3.297 \cdot 10^{-6}$ & $-1.438 \cdot 10^{-9}$ & $1.107 \cdot 10^{-12}$ \\
\hline \multirow{4}{*}{$\begin{array}{l}\text { Spinach } \\
\text { leaves }\end{array}$} & \multirow{4}{*}{$\mathrm{Pb}$} & 11.382 & 0.198 & 0 & 0 & 0 & 26.637 \\
\hline & & 5.845 & 0.333 & $-4.378 \cdot 10^{-4}$ & 0 & 0 & 14.31 \\
\hline & & 2.433 & 0.593 & $-3.487 \cdot 10^{-3}$ & $7.663 \cdot 10^{-6}$ & 0 & 4.13 \\
\hline & & 0.897 & 0.83 & $9.399 \cdot 10^{-3}$ & $5.346 \cdot 10^{-5}$ & $-9.794 \cdot 10^{-8}$ & $1.556 \cdot 10^{-13}$ \\
\hline \multirow{4}{*}{ Cucumbers } & \multirow{4}{*}{$\mathrm{Cu}$} & 0.19 & $-3.136 \cdot 10^{-4}$ & 0 & 0 & 0 & 169.64 \\
\hline & & 0.245 & $-1.094 \cdot 10^{-3}$ & $1.148 \cdot 10^{-6}$ & 0 & 0 & 123.307 \\
\hline & & 0.286 & $-2.288 \cdot 10^{-3}$ & $5.738 \cdot 10^{-6}$ & $-4.372 \cdot 10^{-19}$ & 0 & 99.395 \\
\hline & & 0.415 & $-7.355 \cdot 10^{-3}$ & $3.904 \cdot 10^{-5}$ & $-7.634 \cdot 10^{-8}$ & $4.936 \cdot 10^{-11}$ & $4.653 \cdot 10^{-12}$ \\
\hline
\end{tabular}

Similar results for all the vegetables mentioned, moreover in contaminated soil with mixtures of heavy metals are found in [13-15].

In another studies from Romania was realised monitor the heavy metal $(\mathrm{Cr}, \mathrm{Cd}, \mathrm{Cu}, \mathrm{Pb}$ and $\mathrm{Zn})$ in plant soilsystems thus: in [16] from the polluted area Tarnaveni, to accomplish a comparative study on Cirsium arvense and Agropyron repens heavy metals uptake; in [17] in the vicinity of tailing deposits from Baia Mare mining area to assess the availability of these metals to vegetables by computing the vegetables (cabbages, carrots) uptake factors; in [18] potentially toxic heavy metals $(\mathrm{Pb}, \mathrm{Hg}, \mathrm{Cd}$ ) in popular medicinal herbs (Hypericum perforatum, Artemisia absinthium, Chelidonium majus, Crataegus monogyna), from spontaneous flora bordering coal power plants from localities, Țînțăreni and Valea Văii (Targu Jiu).

\section{Conclusions}

Following the experiments and the statistical processing of their results, as general phenomenology it is noted that:

- until the end of the vegetation stage (harvest) the plants considered in experiments continuously accumulate (monotonously increasing) heavy metals from the contaminated soil;

- the transfer coefficient decreases with the increase in heavy metal concentration in the soil, at least until the end of the vegetation period (harvest).

The results obtained for vegetables show that such statistical experiments and modeling can provide the basis for the construction of dynamic mathematical models that can simulate the life of a plant, even of several generations of plants, and highlight potential mechanisms of self-defence developed by plants, adaptation to new/variable environmental conditions (climate change), possibilities of plant qualities recovery in time.

Acknowledgments: This paper was financed by support of Executive Agency for Higher Education, Research, Development and Innovation Funding, Exploratory Research Programme, PN-III-P4-ID-PCE-2016-0860, contr. 174/ 08.08.2017, Research on the development of some mathematical models to evaluate the impact of soil contamination on fruits and vegetables - CONTAMOD".

\section{References}

1. CARDEI P., TUDORA C., Theoretical research on evolution of health of plant affected by heavy metal absorption process, Engineering for Rural Development, Jelgava, 2018, p. 893-897. DOI: 10.22616/ERDev2018.17.N186

2. INTAWONGSE M., DEAN R. J., Uptake of heavy metals by vegetable plants grown on contaminated soil and their bioavailability in the human gastrointestinal tract, Food Additives \& Contaminants, volume 23, issue 1, 2007, p. 36-48.

3. SUBHASHINI V., SWAMY A.V.V.S, HEMA KRISHNA R., Pot experiment: to study the uptake of zinc by different plant species in artificially contaminated soil, World Journal of Environmental Engineering, 1 (2), 2013, p. 27-33.

4. NASER H.M., SULTANA S., MAHMUD N.U., GOMES R., NOOR S., Heavy metal levels in vegetables with growth stage and plant species variations, Bangladesh J. Agril. Res., 36 (4), 2011, p. 563-574

5.CARDEI P., TUDORA C., Simulation of mechanism on the calculation and transfer of heavy metals in plants, 2018, DOI:10.13140/RG.2.2.22779.82720

6. NEDELESCU M., BACONI D., NEAGOE A., IORDACHE V., CONSTANTINESCU P., CIOBANU A. M., VARDAVAS I. A., STAN M., VINCETI M., TSATSAKIS M. A., Environmental metal contamination and health impact assessment in two industrial regions of Romania, Science of the Total Environment 580, 2017, pp 984-995.

7. DING C., MA Y., LI X., ZHANG T., WANG X., Determination and validation of soil thresholds for cadmium based on food quality standard and health risk assessment, Science of the Total Environment 619-620, 2018, p. 700-706.

8. AUGUSTSSON A.L.M., UDDH-SÖDERBERG T. E., HOGMALM K. J., FILIPSSON M.E.M., Metal uptake by homegrown vegetables The relative importance in human health risk assessments at contaminated sites, Environmental Research 138, 2015, p. 181-190. 
9. ZHOU H., YANG W.-T., ZHOU X., LIU L., GU J.-F., WANG W.-L., ZOU J.-L., TIAN T., PENG P.-Q., LIAO B.-H, Accumulation of heavy metals in vegetable species planted in contaminated soils and the health risk assessment, Int. J. Environ. Res. Public Health 13, 289, 2016; doi:10.3390/ijerph13030289.

10. HURA C., MUNTEANU N., STOLERU V., Heavy metals levels in soil and vegetables in different growing systems, E3S Web of Conferences, 1, 08007, 2013, DOI: 10.1051/e3sconf/20130108007

11. GERGEN, I., Chemical and physicochemical methods in the control of vegetable agrifood products quality, Orizonturi Universitare Publishing House, 2003, Timisoara

12. MOKGOLELE, M., LIKUKU,S.A., Preliminary investigation of transfer of metals from soil to vegetables: Case study of Spinacia oleracea L., African Journal of Environmental Science and Technology, 10 (9), 2016, p. $307-313$

13. ***https://www.inma.ro/.../Proiect_0860_vladut.pdf

14. PRUTEANU.A., BORDEAN D.M., VLADUT V., Accumulation of heavy metals in vegetables grown on contaminated soils, 47 Symposium "Actual Tasks on Agricultural Engineering", Opatija, Croatia, 2019 (In process of publication).

15. PRUTEANU A., BORDEAN D. M., VRÎNCEANU N., VLĂDUȚ V., NIȚU M., GĂGEANU I., CABA I. - Researches on soil contamination with heavy metals and their remanence in vegetables, Annals of the University of Craiova - Agriculture, Montanology, Cadastre Series, Vol. XLVIII, 2018, p. 393-398.

16. SIMION A., NITA S., DUMITRU NITA L., RADA M., BORDEAN D. M., ALDA L. M., Heavy metals (Cr, Cd, Cu, Pb and Zn) uptake by Cirsium arvense and Agropyron repens, Rev. Chim., 69, no. 5, 2018, p. 1145

17. MICLEAN M., LEVEI E.-A., SENILA M., ROMAN C., CORDO E., Assessment of $\mathrm{Cu}, \mathrm{Pb}, \mathrm{Zn}$ and Cd availability to vegetable species grown in the vicinity of tailing deposits from Baia Mare area, Rev. Chim., 60, no. 1, 2009, p.1

18. NICA BADEA D., Determination of potentially toxic heavy metals $(\mathrm{Pb}, \mathrm{Hg}, \mathrm{Cd})$ in popular medicinal herbs in the coal power plant area, Rev. Chim., 66, no. 8, 2015, p. 1132

Manuscript received: 2.04 .2019 